\title{
Genius loci
}

\author{
Jan Musil \\ Univerzita Jana Evangelisty Purkyně v Ústí nad Labem, Pedagogická fakulta, Katedra \\ preprimárního a primárního vzdělávání
}

Redakci zasláno 15. 12. 2020 / upravená verze obdržena 16. 2. 2021 /

/ k uveřejnění přijato 18. 2. 2021

\begin{abstract}
Abstrakt: Esej se věnuje fenoménu, který se při uchopení vhodným způsobem může stát pevnou součástí výuky v českých školách: je to genius loci a s ním související výuka. V kontextu probíhajících diskusí nad novou podobou kurikula, rychlých proměn společnosti posledních dvou desetiletí a zejména výhledu na budoucí vývoj (nejen) českého přírodního prostředí je rozvoj poznání krajiny žádoucí. Probíhající procesy a jevy v krajině z pohledu přírodovědného i pedagogického poskytují široké možnosti pro objektivní hodnocení a kognitivní složku žákovské osobnosti. Environmentální rozměr s krajinou svázané výuky ohlížející se od lokálních aspektů ke globálním úkolům a problémům rozšiřuje také osobnostní a subjektivní pojetí místa. A nakonec praktické zkušenosti a rozvoj kompetencí vedle znalostí završují využití a použití daného místa žáky v intencích místně zakotveného učení. Esej je rozčleněna na dvě části, kdy je první věnována teoretickým východiskům, seznámení s klíčovými faktory obou fenoménů a jejich rizikům; druhá pak sleduje kontext kurikulárních dokumentů, výuky a místně zakotveného učení na příkladech pedagogické praxe. $\mathrm{V}$ závěru se př́spěvek věnuje náhledu na terénní výuku a místně zakotvené učení jako nástroje participace žáků na utváření, upevňování a uchování genia loci v úrovni znalostí, hodnot, spolupráce komunity, sdílené paměti a společných tradic.
\end{abstract}

Klíčová slova: místně zakotvené učení, genius loci, místo, identita, výuka

České školství i vzhledem k současnému stavu společnosti stojí před mnoha výzvami. Jednu z nich představuje úprava vzdělávacího obsahu, jež je diskutována v souvislosti s revizí rámcových vzdělávacích programů. Školský mainstream pracuje $\mathrm{s}$ řazením tematických celků $\mathrm{v}$ rámci vzdělávacích oblastí a z nich vycházejících předmětů, ve světě (např. USA, Finsko) můžeme najít vícevrstvé modely předmětových bloků, projektové a problémové výuky, holistický model STEM a další. Nesporně zajímavé podněty může přinášet i zdánlivě jednoduchý pojem: MÍSTO. 


\section{Hic sunt leones}

Těmito slovy vyplňovali kdysi kartografové tzv. bílá místa $\mathrm{v}$ mapách. Označovaly se jimi lokality tehdejším lidem neznámé, skrývající nové poznání, civilizace a možná i riziko (odtud oni zmiňovaní lvi). Právě koncept místa byl shledán jako jeden z klíčových termínů geografického vzdělávání (IGU, 1992) a promítá se do mnoha disciplín: architektury, historie, lingvistiky, výtvarné kultury atd. Nakonec samotné slovo geografie skrývá pojem místo ve své podstatě.

Pokud budeme uvažovat - podobně jako geografové a environmentalisté o další úrovni fundamentu, nutně narazíme na vztahy mezi jednotlivými prvky a jevy, v současné době téměř vždy v kontextu lidské existence a jejího vlivu na dané prvky či jevy (Gruenewald, 2003). V tomto ohledu můžeme vycházet z tezí IGU (1992, s. 10) o vzájemné provázanosti fyzické podstaty místa s jejím kulturním potenciálem.

Betrand (1998) poskytuje ve svém přehledu základní sumu informací o ekosociálním přístupu k edukaci, kterou prostupuje synergie environmentálního prostoru a sociálního rozměru vzdělávání, a měla by tím směřovat k udržitelnému chování a žádoucí aktivitě žáka jako jedince uvědomělého a odpovědného k sobě samému, jakož i k prostředí, v němž se pohybuje/žije.

Jde tak vlastně o návrat k mytologickému souladu s krajinou, jak ji nastiňuje Machovec (1998, s. 74-76), když jeden ze základů katarze současného světa spatřuje právě v renesanci jednoty př́rody a člověka z úrovně materia (zdroj suroviny a obživy) do roviny natura (člověk je součástí krajiny). Kohák (2011, s. 66) k tomu souhlasně dodává, že ztrátou přirozeného prostředí ztrácíme schopnost přirozeně se chovat. $V$ duchu naessovské hlubinné ekologie Kohák rozvíjí více vrstev vztahu člověka a jeho prostředí, které nabízí hlubší úrovně poznání místa. Filosofický rozměr místa nastiňuje Norberg-Schulz (1994) jako fenomén, jenž tvoří integrální část existence: bez místa nelze interpretovat událost. $V$ celkovém historickém obrazu střední Evropy touto optikou rozkrýváme velmi pestrou a složitou strukturu libovolného místa, což je reflektováno v mnoha mediálních obrazech. I z tohoto pohledu se jeví místo jako multidisciplinární a multifaktoriální koncept, který lze popisovat zdánlivě pouze holistickým principem a použít ve stejném duchu (Betrand, 1998; Sobel, 2013a, 2013b). 
Samotné poznání místa je čistě individuální proces, který je navíc diferencován na základě vývoje poznávajícího jedince. Přihlédneme-li k postupnému vývoji lidské psychiky, nabízí se Vygotského teze o zóně proximity (Bertrand, 1998), již aplikujeme na lexikální definici místa a zároveň i prostorové vymezení. Vygotskij vývoj dětského poznání váže k vývoji řeči a onou zónou proximity chápe nejbližší možnou dosažitelnou oblast poznání, kterou dítě může reálně poznat. Pro prostorovou orientaci lze odvozovat podobné schéma. Sobel (2013a) k tomu podotýká, že osobní prožitek se v poznávání místa promítá s ohledem na věk jedince do rozměru místa (Obr. 1). Otázkou pro výzkumnou praxi zůstává míra internalizace prostoru.

\section{Obrázek 1}

\section{Hranice poznávání prostoru}

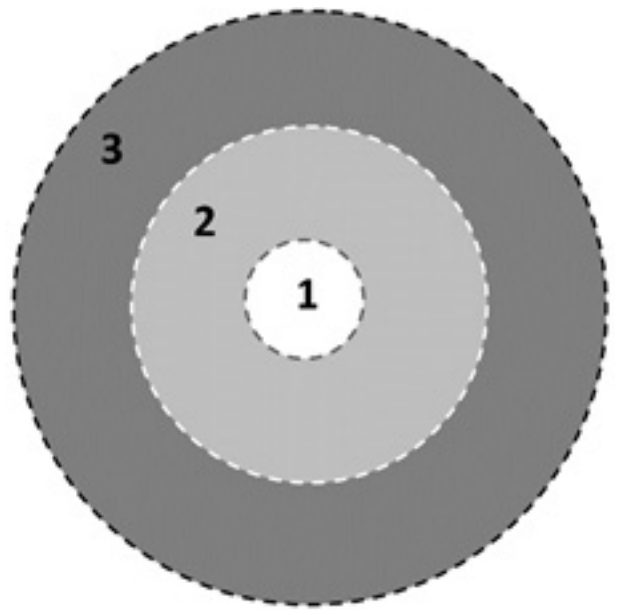

Sobel (2013a) uvádí pro vývoj dětského pojetí místního regionu tři fáze odstupňované podle věku a areálu pohybu. Raná (1) fáze se odehrává ve věku do 7 let v blízkosti domu, střední (2) rozvíjí věk 8-11 let v rámci ulice a v periferiích dosud poznaného prostoru. Vrcholná fáze (3) následuje od 12 let a pokrývá místa sociálních vazeb v rámci obce a regionu. Hranice mezi jednotlivým fázemi nejsou přesně dané a ostře vymezené v prostoru. 
Místo jako prostor poznaný a poznávaný tak přímo ovlivňuje identitu jedince, když působí na psychickou strukturu osobnosti. V rámci komunity, společnosti v daném prostoru, pak hovoříme o kolektivním ovlivnění sdíleného kulturního vědomí, které spoluvytváří sociální identitu. Koncept regionu jako sociálního konstruktu shrnuje Marek (2020) se zřetelem k Paasiho sociálně-geografické teorii.

\section{Genius}

Fergusson $(2019$, s. 397) popisuje na příkladu náměstí Palazzo Publico v italské Sieně rozdíly ve vnímání prostoru v kontextu horizontální a vertikální dělby společnosti a dále rozvádí mocenské uchopení prostoru. Souhlasně $\mathrm{s}$ takovým viděním místa lze sledovat obdobné teze $\mathrm{v}$ historickém (Schama, 2007), architektonickém (Norberg-Schulz, 1994) či generalizujícím filosofickém směru (Machovec, 1998; Kohák, 2011). Je místo nástrojem moci?

\subsection{Genius objektivní}

Genius loci bývá překládán jako duch místa. $\mathrm{V}$ rozšířené metafoře můžeme hovořit také o duši místa, uvědomující si všechny rozměry daného prostoru (Vecco, 2020). Norberg-Schulz (1994, s. 11-13) rozšiřuje terminologii o charakter místa, jenž označuje „celkovou atmosféru“ a zároveň „vše, co je skutečně přítomné“. Nutno dodat, že stejně jako záleží na struktuře místa samotného ve smyslu jeho přísné multifaktoriální charakteristiky (geografická, historická, ekonomická, sociologická atd.), klíčový je rovněž vztah k dalším místům, osobám a událostem, jež s definovaným místem vstupují do interakce (vzájemně se ovlivňují; Norberg-Schulz, 1994; Schama, 2007; Sobel, 2013b).

Kolejka (2013) se zaměřuje na vrstvy krajiny: rozlišuje čtyři úrovně krajinné struktury (přírodní, hospodářskou, společenskou a duchovní), přičemž duchovní transmisivní část je zastřešující. Samotný pojem genia loci definuje jako „symbolický prostorový vzor krajiny daný imaginárními i skutečnými událostmi“ (Kolejka, 2013, s. 57). Vecco (2020) navazuje se skrytým významem termínu; chápe jej jako přenášené historické dědictví, respektive jako identifikační rámec společnosti. Bez (re)interpretace místa a jeho významu nelze budovat společenství (Vecco, 2020; Schama, 2007). 
Pokračujeme-li v rozšiřování definice, dostáváme se k metakonceptu genia loci, jenž je tvořen sumou měkkých a tvrdých dovedností (soft and hard skills). Ty stanovují subjektivní (osobní, např. pocit) a objektivní (měřitelnou, např. nadmořská výška) povahu místa (Vecco, 2020). V rámci každé hodnoty lze dále interpretovat jednotlivé vrstvy místa do libovolných úrovní v geografickém chápání prostoru (Kolejka, 2013, s. 59-61).

\subsection{Genius kulturní}

Vedle objektivních (tvrdých) hodnot se ovšem výrazně projevuje také ona nepopsatelná vrstva místa, která je založena na kulturním kapitálu.

Schama (2007, s. 272) popisuje hledání kořenů sounáležitosti mezi lidmi v různých prostředích na základě mýtů, jež vyšly z reakcí společnosti na přírodní jevy a prvky. Implikuje tedy neustálou interakci člověka a prostředí. Navíc v takovém vztahu musíme neustále zvažovat měnící se podmínky, nebot' v př́rodě neexistuje terminální, věčná struktura. Vecco (2020) to ovšem bere jako výrazný benefit, nebot' umožňuje vlastně neustálou transmisi kulturního kapitálu genia a jeho rekonstrukci (Obr. 2) v rámci společnosti. Na základě historické zkušenosti lze tvrdit, že čím větší význam má dané místo v tzv. velkých dějinách, tím větší je společenský dosah a dopad tohoto procesu (Stradling, 2001).

\section{Obrázek 2}

Interpretace a rekonstrukce genia loci

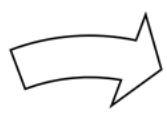

\section{PŘENOS}

FORMULACE

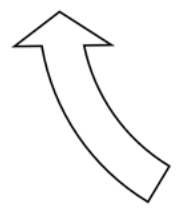

OCHRANA

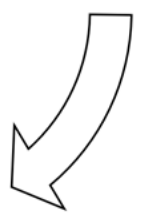


Princip rekonstrukce genia loci na základě změn ve společnosti počítá rovněž s aktualizací všech složek kapitálu: kulturního, lidského i sociálního. Zvnitřněním jejich podstaty se rozvíjí potenciál místa a uchovává či rekonstruuje pamět' místa (Vecco, 2020). Z minulosti známe ovšem i negativní vývoj. V takovém př́ípadě může dojít $\mathrm{k}$ dekonstrukci: společenská krize vede ke krizi prostředí, a naopak (Machovec, 1998, s. 76-78; Norberg-Schulz, 1994, s. 191; Schama, 2007, s. 148-149).

\subsection{Genius univerza}

Souhlasně s Veccem (2020, s. 228) i Kolejkou (2013) berme fenomén genia loci jako proměnlivou část krajinné sféry. Ona proměnlivost je dána naším individualizovaným prožitkem určitého místa za konkrétních, neopakovatelných podmínek. Rigidní a všeobjímající definice v takovém prostředí neobstojí. Multidisciplinarita tématu poskytuje vícevrstvá vysvětlení a v aplikaci na konkrétním místě může nabídnout zdánlivě uspokojivý výsledek.

Rychlost proměny krajiny pod rukama člověka ovšem nezvládá reagovat na rekonstrukci genia loci, čímž dochází ke vzniku reziduí a fragmentů geniů loci ve zvláště exponovaných regionech. ${ }^{1}$ Pedagogická práce s těmito fenomény (např. zaniklé obce, vysídlení obyvatel, zbytky sídel v krajině) poskytuje nadmíru zajímavé možnosti, přičemž by v tomto případě měl mít pedagog na zřeteli korektní práci s konceptem genia loci: relevantní a fakty podložená rekonstrukce (či renesance) směřuje k oslabené fragmentární skutečnosti a může ji posílit (či obnovit).

\section{Proměny krajiny}

Ve spojitosti s nepřetržitým vývojem krajiny ve všech úrovních, rozměrech, strukturách a souvislostech musíme revidovat/rekonstruovat také kompendium našich poznatků o daném místě. Kvalitativní či kvantitativní změna prostředí podle výše uvedeného ovlivní také genia loci. Budou-li tyto změny negativní, ohrožují samotnou podstatu konceptu: nedostatek charakteru působí chudobu podnětů, čímž dochází k devalvaci metahodnoty krajiny (Norberg-Schulz, 1994, s. 190). Regrese či úplné vymizení genia loci daného místa pak cele ovlivňuje vnímání v rámci sociální skupiny. Výjimečně dochází v kulturní krajině k renesanci (ve smyslu znovuzrození) genia loci s novou

1 V současnosti existuje bohatá literatura věnovaná tématu, namátkou: Antikomplex a kol. (2015); Jeleček, L. (2005); Mikšíček, P. (2005). 
funkcí krajinného spektra, např. formou rekultivace postindustriálního prostoru. Je pak ovšem úkolem sociologického či kulturně-antropologického výzkumu zjistit, jakou formu, podobu, strukturu a dosah nový fenomén naznává?

Do proměny fyzické podstaty krajiny promlouvají mnohé procesy s odlišnou délkou trvání, jež jedinec často nedokáže v osobním časovém horizontu identifikovat (např. eroze v aridní oblasti či proces vrásnění). Namísto toho jedinec postihne krátký časový úsek a subjektivně vyhodnocuje změny krajiny na nízkém stupni prostorové kognice. Sobel (2013a, s. 25) vztahuje takové hodnocení místa k věku dítěte, které vzhledem k úrovni dosavadního poznání nedokáže adekvátně hodnotit všechny informace, když hovoří o ignoraci vzdálenosti dětmi předškolního a mladšího školního věku. Generalizace probíhá „za psychologickým rohem“ dítěte bez ohledu na skutečný geografický rozměr (Sobel, 2013a, s. 13).

Zvláštní pozornost zasluhuje v českém krajinném prostředí výše zmíněná renesance genia loci. Za posledních 80 let na území Československa, resp. Česka bylo zničeno nejméně na dva tisíce obcí, jejich částí i samostatných významných objektů, které se podílely na vytváření duše míst. ${ }^{2}$ Rekultivace je jednou z cest a probíhá aktuálně zejména v těžebních lokalitách (severozápad Čech, Ostravsko ad.). Z hlediska potenciálu aktivního návratu (Machovec, 1998, používá termínu re-creatio) genia loci v člověkem opuštěné krajině vystupuje transmise tradice jako obnovení funkcí, typologie, konstrukce a vlastního pojetí místa. Proces obnovení mívá různou intenzitu, používá ale téměř vždy principy aktivní občanské společnosti, vytváření ideje domova, zkušenostní a experimentální př́ístupy či obecně platné environmentální zásady péče o krajinu (Gruenewald, 2003; Kolejka, 2013; Sobel, 2013b; Vecco, 2020).

\section{Společně}

Vecco (2020) navrhuje, aby jedinec přistoupil k místu jako sdílené historické tradici, zatímco se stává její součástí. Metakoncept může být zachován pouze aktivní interpretací a dalším přenosem. Tak je předávána nejen zkušenost a znalost, nýbrž i lokální identita (Norberg-Schulz, 1994, s. 202). Kauzalita procesu modelování genia loci se tak stává integrální součástí lidského

2 Číselný údaj vychází z volně dostupné databáze na webové stránce http://www.zanikleobce.cz. 
myšlení i fyzické podstaty (srov. Kohák, 2011, s. 73-85; Kolejka, 2013, s. 297; Schama, 2007, s. 333 an.).

Prostředí české školy nabízí konceptu genia loci jedinečné možnosti v transmisi souhrnné tradice. Kurikulum přímo vybízí k realizaci reinterpretací místa, kde žijeme, přičemž důraz klade na „praktické poznávání místních a regionálních skutečností" (MŠMT, 2017, s. 42). Současná publikační šíre metodických materiálů pedagogické veřejnosti předestírá benefity mnoha metod a forem, jež naplňují jednak požadavky kurikula, jednak filosofický rozměr konceptů místa i environmentální výchovy. Mezi nimi nalézáme koncepční materiály (Svobodová et al., 2019), teoretické studie (Daniš, 2019; Sobel, 2013b), praktické náměty pro přímou aplikaci ve výuce (Kř́ž, 2017) či kombinované texty (Pluháčková et al., 2019; Sobel, 2013a).

Aktivizace jedince (bez ohledu na věk) přináší místu obohacení, byt' můžeme následně při transmisi narážet na problémy sdílené společné paměti: dochází ke zkreslení (idealizování) místa projektovanému do minulosti (Stradling, 2001, s. 106). V tomto ohledu vyvstává znovu multidisciplinarita genia loci jako maják přinášející orientaci. K místu můžeme totiž přistoupit jako k polystrukturní entitě, částečně odbourat nespolehlivou lidskou pamět' přímých svědků a použít model místně zakotveného učení (Gruenewald, 2003; Sobel, 2013b). To spojuje de facto všechny úrovně poznání ve zdánlivě holistickém modelu poznání. Záleží pak na konkrétním pedagogickém vedení, jakým směrem bude proces poznávání místa dále řídit. Daniš (2019) tvrdí, že většina (ne-li všechna) témata vzdělávání lze převést do venkovní výuky. Pro př́íklad: Z úvodního, ryze geografického zadání komplexní charakteristiky místa může žák dle svých individuálních schopností a prožitku vytvořit mentální mapu, land art, literární dílo. Všemi těmito postupy dojde k reformulaci genia loci v osobní rovině a pří sdílení se skupinou o úroveň dál.

\section{Závěrem}

Sobel (2013a, 2013b) a Gruenewald (2003) publikovali v odlišném smyslu podobné texty: místně zakotvené učení jako pedagogické uchopení místa dodává terénní výuce (Svobodová et al., 2019) sociální rozměr. Zdánlivě shodný kontext (či princip) pojetí místa se právě v jistém směru personifikuje každému žákovi ve shodě s intencemi rámcových vzdělávacích programů a v nich obsaženým rozvojem žákovských kompetencí. Znalostní báze učení ustupuje do pozadí ve prospěch prosociálních, environmentálních a 
rozvojových dispozic žáka: v aktuálních vzdělávacích plánech lze uplatnit místně zakotvené učení v oblastech Člověk a společnost, Člověk a příroda, Jazyk a jazyková komunikace, Matematika a její aplikace a dále. Na př́kladu rekonstruované synagogy v Hartmanicích lze tak sledovat historii stavby i v místě (dříve i nyní) žijících lidí, krajinu Hartmanic, místní dialekt či vztahy česko-německého pomezí Šumavy, geometrii architektury horské synagogy až po digitalizaci celého prostoru. Konkrétní rozpracování pedagogické aplikace vybraného místa záleží vždy na požadavcích pedagogů, sledování naplnění vytčených cílů a dalších parametrech, jimiž místo disponuje. Zmínku si jistě zaslouží příprava: ačkoliv Sobel (2013b) na několika příkladech uvádí jisté výhody naprosté volnosti při poznávání a zpracovávání lokality žáky, je otázkou, co má být cílem aktivity - jasně daný a precizovaný cíl, nebo cesta $\mathrm{k}$ němu?

Sun'C (544-496 př. n. l.) napsal, že sice existuje pět základních barev, ale jejich kombinací dostaneme tolik odstínů, že je za celý život nepoznáme. My dnes dokážeme rozlišit miliony odstínů, ovšem každý vnímáme subjektivně. Tato analogie ke geniu loci je na místě, nebot' právě možnost individuálního hodnocení působení místa na lidskou psychiku i fyzickou podstatu činí koncept duše místa tak originálním, přenositelným a sdíleníhodným.

Dnes stojíme před výzvou přímo existenciální: lze využít rychle se měnící svět a náš osobní habitus ke změně vztahu právě k přírodě v zájmu člověčenství? Od technicistního pojetí krajiny se častěji vracíme zpět k mytologickému vztahu jedinec-prostředí. ${ }^{3}$ Genius loci je myšlenkový konstrukt, neexistuje jako hmatatelná entita, ačkoliv právě hmatem vnějším (smysl) i vnitřním (idea) jej tvoříme.

\section{Literatura}

Antikomplex a kol. (2015). Zmizelé Sudety. Antikomplex.

Bible (2015). Bible: preklad 21. století. Biblion.

Bertrand, Y. (1998). Soudobé teorie vzdělávání. Portál.

Daniš, P. (2019). Tajemství školy za školou. Ministerstvo životního prostředí.

Fergusson, N. (2019). Věž a náměstí. Argo, Dokořán.

Gruenewald, D. (2003). The best of both worlds: A critical pedagogy of place. Educational Researcher, 32(4), 3-12.

IGU (1992). International charter on geographical education. CGE.

3 „Prvního dne prvního měsíce vztyčíš Př́ibytek, Stan setkávání.“ (Ex 40, 2; Bible 2015). 
Kohák, E. (2011). Zelená svatozář. Sociologické nakladatelství.

Kolejka, J. (2013). Nauka o krajině. Academia.

Kříž, M. (2017). Krajina nápadů. Apis Press.

Jeleček, L. (2005). Sudety a sudetští Němci. Geografické rozhledy 14(5), 118-119.

Machovec, M. (1998). Filosofie tvář́ v tvář zániku. Zvláštní vydání.

Marek, P. (2020). Region coby sociální konstrukt a kritická diskuze Paasiho konceptualizace regionální identity. Geografie, 125(1), 47-68.

Mikšíček, P. (2005). Sudetská pout' aneb Waldgang. Dokořán.

MŠMT (2017). Rámcový vzdělávací program. NÚV.

Norberg-Schulz, C. (1994). Genius loci. Odeon.

Pluháčková, M., Duffek, V., Stacke, V., \& Mentlík, P. (2019). Kritická místa kurikula zeměpisu na 2. stupni základní školy I. Západočeská univerzita.

Schama, S. (2007). Krajina a pamět'. Argo.

Sobel, D. (2013a). Beyond ecophobia. The Orion Society.

Sobel, D. (2013b). Place-based education. The Orion Society.

Stradling, R. (2001). Jak učit evropské dějiny 20. století. MŠMT.

Svobodová, H., Mísařová, D., Durna, R., Češková, T., \& Hofmann, E. (2019). Koncepce terénní výuky pro základní školy. Masarykova univerzita.

Vecco, M. (2020). Genius loci as a meta-concept. Journal of Cultural Heritage, 41, 225-231.

\section{Autor}

Mgr. Jan Musil, Univerzita Jana Evangelisty Purkyně v Ústí nad Labem, Pedagogická fakulta, Katedra preprimárního a primárního vzdělávání, Hoření 13, 40096 Ústí nad Labem, e-mail: janxmusil@gmail.com

\section{Genius loci}

Abstract: The essay deals with the phenomenon which, when grasped in a suitable way, can become an integral part of teaching in Czech schools: it is genius loci and related instruction. In the context of ongoing discussions on the new form of the curriculum, on the rapid changes in society over the past two decades and especially on the outlook for the future development of (not only) the Czech natural environment, we recognize the importance of the development of knowledge of the landscape. All existing processes, phenomena and landscape in general provide wide range for evaluation and cognitive part of children's personality. The environmental dimension, ranging from local aspects to global challenges and problems, also extends the personal and subjective conception of the place. Finally, practical experience and the development of competencies, in addition to knowledge, complete the use and application of the place by pupils in the intentions of locally grounded learning. The 
essay is divided into two parts, the first is devoted to the theoretical background, introduction of the key factors of both phenomena and their risks, and the second follows the context of curricular documents, teaching and place-based education on examples of pedagogical practice. Finally, the paper focuses on the view of outdoor education and place-based education as tools for student participation in the formation, consolidation and preservation of the genius loci in the level of knowledge, values, community cooperation, shared memory and common traditions.

Keywords: place-based education, genius loci, place, identity, education 